\title{
The Clinical Application of Platelet Concentrates: A Systematic Meta-analysis
}

\author{
${ }^{1}$ Sneha Ketan Gada, ${ }^{2}$ Pankaj Gupta
}

\section{ABSTRACT}

Background: Autologous plasma rich in platelets is derived blood product whose uses in dentistry dates back to the 1990s and it has been gaining popularity ever since.

Aim: A systematic review of the available literature to determine the efficacy, safety and success of platelet concentrates in physiological systems as well as describing its vigilant use.

Study design and methods: A Medline search with keywords 'platelet rich plasma dental' further filtered using Boolean operators (AND, OR, NOT) and combination of specific keywords as follows: 'platelet rich fibrin', 'platelet rich plasma regenerative', 'platelet rich plasma periodontal', 'platelet rich plasma extraction' with a custom range of 10 years was performed, which yielded 88 results out of which 32 were selected based on the inclusion criteria.

Results: Significantly, successful outcomes have been witnessed in the field of osteoregeneration though it has been evidenced that adequate platelet rich plasma (PRP) additives are essential to bear a therapeutic potential. Favoring blood cell adhesion on the root surface optimizing periodontal healing, PRP has also shown positive effect on gingival repair; though controversial facts have also been reported. In the scope of implant dentistry, PRP has also reported greater implant-bone contact when used in both gel or liquid form. Emerging as a possible pulp capping agent along with properties of decreased chances root growth, PRP has successfully completed apexogenesis in cases of pulpotomy.

Research has shown that although clinical results from the comparison of PRP alone vs PRP and resorbable membrane or various graft materials has shown a varied results, additional research in the field is needed.

Conclusion: Platelet rich plasma has shown promising results in the field of regenerative dentistry, with high success rate in implantology, periodontology and oral surgery. Because of conflicting success rates reported in literature further research is warrented.

Clinical implication: Platelet rich fibrin has displayed various features of rapid clinical healing, excellent bone density, less surgical time, less resorption during healing and decreased postoperative pain, as compared to guided bone regeneration

\footnotetext{
${ }^{1}$ Intern, ${ }^{2}$ Assistant Professor

${ }^{1}$ Nair Hospital Dental College, Mumbai, Maharashtra, India

${ }^{2}$ Department of Conservative Dentistry and Endodontics, Nair Hospital Dental College, Mumbai, Maharashtra, India

Corresponding Author: Sneha Ketan Gada, Intern, Nair Hospital Dental College, Mumbai, Maharashtra, India, Phone: 8097086613 e-mail: snehagada@yahoo.co.in
}

procedures. Platelet rich plasma has also shown a myriad of applications ranging from hard tissue regeneration to soft tissue management, stretching across to the field of pediatric dentistry and endodontics.

Keywords: Platelet rich plasma, Platelet rich fibrin, Metaanalysis, Regenerative dentistry.

How to cite this article: Gada SK, Gupta P. The Clinical Application of Platelet Concentrates: A Systematic Metaanalysis. Int J Prosthodont Restor Dent 2015;5(1):21-26.

\section{Source of support: Nil}

\section{Conflict of interest: None}

\section{INTRODUCTION}

Unveiling platelet rich plasma (PRP) into the field of dentistry dating back to the 1970s has been followed by an era of development. Platelets have held a history of simple hemostasis but scoping beyond its norm, it contains important growth factors which entitle it with the function of increasing cell mitosis, increasing collagen production, recruiting other cells to site of injury, initiating vascular ingrowth and inducing cell differentiation. ${ }^{1}$

Hence, logically increasing platelet concentration equates to increasing growth factors which pronounces rapid healing and regeneration. This concentrated form of platelets is in other words termed as platelet rich plasma, a volume of autologous plasma, labeled inherently safe and free from transmissible diseases that has platelet concentrate above baseline. ${ }^{1,2}$

On one thought were Whitmann et al in 1997 were extolled for introducing PRP into the field of oral surgery, on the other PRP was as not entirely greeted with approval; contradictory results too grasp a slice in literature. ${ }^{3}$ The conflicting results in today's literature make it overwhelmingly evident that more research is needed before evidence-based surgeons can feel confident in recommending this procedure to their patients. Reliable and reproducible animal models have been developed to study this autologous material but welldesigned, rigorous, standardized human trials need to be reviewed to prove its benefit. ${ }^{2,4}$

\section{AIM}

A systematic review of the available literature on human trials was conducted to evaluate efficacy and safety 
of platelet concentrates in physiologic systems and to describe its vigilant use from studies which have shown comparative results.

\section{STUDY DESIGN AND METHODS}

A systematic search of scientific papers published was performed in the electronic PubMed database of Medline and dental journals using specifics keywords 'platelet rich plasma dental' further filtered using Boolean operators (AND, OR, NOT) and combination of specific keywords as follows: 'platelet rich fibrin' 'platelet rich plasma regenerative' 'platelet rich plasma periodontal' 'platelet rich plasma extraction' within the custom range of 10 years. The search was performed upto 1 September, 2014 (Flow Chart 1).

\section{Inclusion Criteria}

Studies were selected if they met the following inclusion criteria: (1) Report written in English (2) human study population (3) all comparative studies which include case reports, case series, original research papers, review papers, in vitro studies and controlled clinical trials on PRP as well as PRF used in dentistry related studies with clinical or radiographic or histologic evidence. In the case of multiple publications of the same study, the one with the most detailed information was included.

\section{Exclusion Criteria}

Studies were excluded if they did not meet the above inclusion criteria or were animal trials.

The electronic search yielded 88 papers; of which 32 papers were retrieved and a review was done that described the efficacious use of PRP and PRF.

\section{Data Collection}

Once a study was included in the analysis, the authors used a predetermined data collection form to extract the following information: (1) The comparison exemplified in the studies with the results seen and (2) Year of publication. Data related to the supporting and contradictory evidences was reported separately. Any disagreements in the data collection reports was resolved by consensus.

\section{RESULTS}

Eighty-eight papers gathered from the search results were further scanned on basis of the inclusion criteria. Thirty two comparative studies including case reports, case series, original research papers, review papers, in vitro studies and controlled clinical trials on PRP as well as PRF used in dentistry related studies with clinical or
Flow Chart 1: The selection process

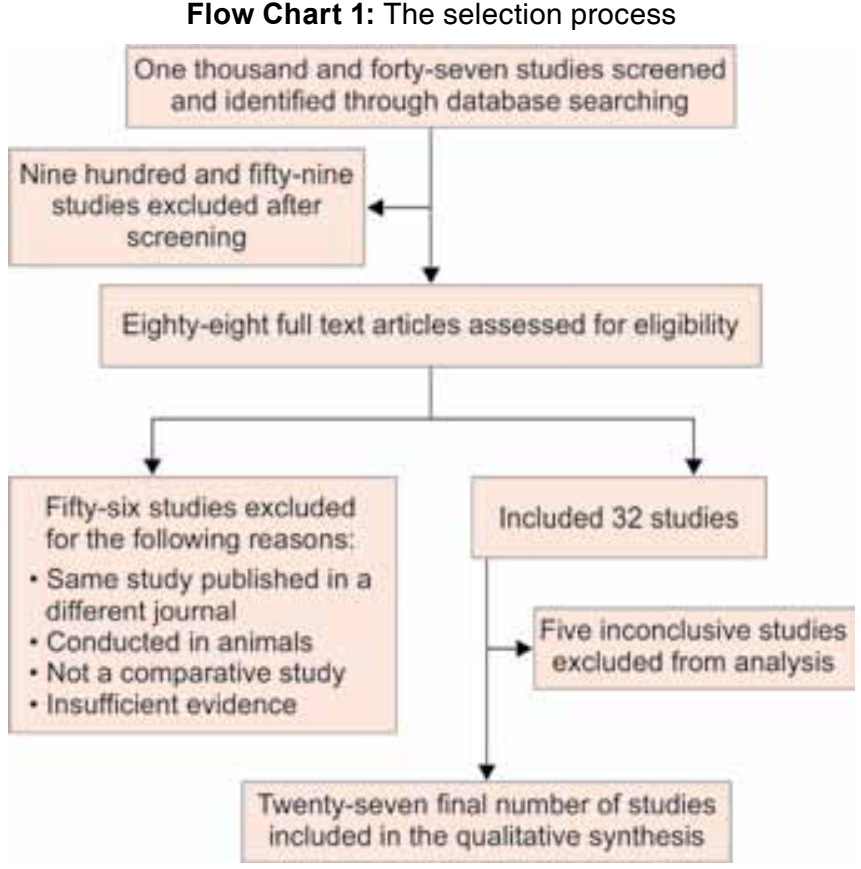

radiographic or histologic evidence. The results of the studies were tabulated and assorted into two categories (Tables 1 and 2). Studies which failed to give conclusive results were excluded.

\section{DISCUSSION}

Development of the bioactive surgical additives is one of the great challenges of clinical research which has been used to regulate inflammation and increase the speed of healing process. ${ }^{5}$ Better understanding of physiologic properties of platelets in wound healing since last two decades led to increase in its therapeutic applications in the various forms showing varying results. As mentioned earlier, platelets isolated from the peripheral blood acts as an autologous source of growth factors in the form of PRP and PRF. ${ }^{1,6}$

Platelet rich plasma, an autologous platelet gel, is an amalgamation of seven known growth factors specifically, platelet derived growth factor as PDGF-AA, PDGF-BB, PDGF-AB, transforming growth factor beta 1 and 2, vascular endothelial growth factor (VEGF), and epithelial growth factor (EGF). Platelet rich plasma is neither a fibrin glue nor osteocondunctive, indeed it simply augments the tissue regeneration and healing. ${ }^{7}$

Approximately, 45 to $55 \mathrm{ml}$ of patient's blood is withdrawn from venous puncture and centrifuged twice to separate red blood cells from plasma and form pure plasma concentrate subsequently. This platelet concentrate is then resuspended in the remaining platelet poor plasma, thereby creating a very concentrated PRP solution. The activator, topical bovine thrombin calcium chloride, is combined with PRP and PPP in a small quantity before use. 
Table 1: Supporting evidences of the meta-analysis

\begin{tabular}{|c|c|c|c|}
\hline SI. no. & Supporting evidences reported & Authors & Year \\
\hline 1. & $\begin{array}{l}\text { PRP and PRF with open flap debridement (OFD) vs OFD showed notable gain in } \\
\text { relative vertical and horizontal clinical attachment level. }\end{array}$ & $\begin{array}{l}\text { Bajaj et al, Pradeep } \\
\text { and et al }\end{array}$ & 2013 and 2012 \\
\hline 2. & $\begin{array}{l}\text { A combination of direct pulp capping agent and PRP increased vital tissue } \\
\text { regeneration within the root canals of immature teeth associated with apical } \\
\text { periodonitis. }\end{array}$ & Zhu W & 2013 \\
\hline 3. & $\begin{array}{l}\text { Marked radiographic difference in periapical healing, apical closure and dentinal } \\
\text { wall thickening revascularization carried out with PRP than without. }\end{array}$ & Jadhav et al & 2012 \\
\hline 4. & $\begin{array}{l}\mathrm{HA}+\mathrm{PRP} \text { (experimental group) or HA + saline (control group): postoperative } \\
\text { difference seen in the probing depth, attachment levels and bone measurements } \\
\text { were statistically significant for the experimental group. }\end{array}$ & Menezes et al & 2012 \\
\hline 5. & $\begin{array}{l}\text { PRP mixed with calcium sulfate hemihydrate showed greater vital bone volume at } \\
3 \text { months with rapid enhancement of bone healing compared to PRP free collagen } \\
\text { resorbable graft. }\end{array}$ & Kutkut et al & 2012 \\
\hline 6. & $\begin{array}{l}\text { PRP treated extraction sites reach comparable bone density in } 1 \text { week as compared } \\
\text { to control sites in } 6 \text { weeks. }\end{array}$ & $\begin{array}{l}\text { Rutkowski et al, } \\
\text { Antonello et al }\end{array}$ & 2010 and 2012 \\
\hline 7. & $\begin{array}{l}\text { Periapical healing with bone formation was more in relation to site grafted with PRP } \\
\text { compared to control site without PRP. }\end{array}$ & Parikh et al & 2011 \\
\hline 8. & $\begin{array}{l}\text { PRP with } \beta \text { TCP revealed significant reduction in probing pocket depth and mean } \\
\text { gain in clinical attachment level with linear bone fill as compared to TCP alone. }\end{array}$ & Saini et al & 2011 \\
\hline 9. & $\begin{array}{l}\text { PRP with } \beta T C P+H A \text { revealed significant reduction in probing pocket depth and } \\
\text { better graft remodeling as compared to } \beta T C P+H A \text { alone. }\end{array}$ & Kaushick et al & 2011 \\
\hline 10. & $\begin{array}{l}\text { PRP vs control extraction socket showed notable reduction in probing depth and an } \\
\text { improvement in the probing attachment level as well as new bone tissue in defect. }\end{array}$ & $\begin{array}{l}\text { Sammartino et al, } \\
\text { Oqundipe et al }\end{array}$ & 2008 and 2011 \\
\hline 11. & $\begin{array}{l}\text { BPBM/GTR/PRP (experimental group) or with BPBM/GTR (control group): } \\
\text { postoperative difference seen in the probing depth, attachment levels and bone } \\
\text { measurements were statistically significant for the experimental group. }\end{array}$ & Camargo et al & 2009 \\
\hline 12. & $\begin{array}{l}\text { PRF appears to be superior to collagen (Bio-Guides) as a scaffold for human } \\
\text { periosteal cell proliferation. }\end{array}$ & Gassling & 2002 \\
\hline 13. & PRF in the sinus (BAOSFE) leads to endosinus bone gain. & Diss et al & 2008 \\
\hline 14. & $\begin{array}{l}\text { Addition of PRP to connective tissue graft membrane resulted in increased width } \\
\text { of keratinized tissue and advanced tissue healing. }\end{array}$ & Jankovic et al & 2007 \\
\hline 15. & $\begin{array}{l}\text { Histologic sample from } 4 \text { months of healing time from group grafted with PRF and } \\
\text { FDBA was identical to that of control group grafted with FDBA alone. }\end{array}$ & Choukroun et al & 2006 \\
\hline 16. & PRP comparable to MTA for incomplete apex formation. & Keswani et al & 2005 \\
\hline 17. & $\begin{array}{l}\text { PRP with autogenous bone graft } 88 \text { patients with mandibular continuity defects } \\
\text { were randomized to be reconstructed with autogenous cancellous bone grafts with } \\
\text { or without addition for PRP, showing } 1.6 \text { to } 2.2 \text { times faster degree of maturation } \\
\text { and significantly greater percentage of trabecular bone. }\end{array}$ & $\begin{array}{l}\text { Marx et al supported } \\
\text { by Garg et al }\end{array}$ & 2004 \\
\hline
\end{tabular}

Evolving further PRF is a second-generation platelet aggregation fibrin-rich gel produced from the venous blood by single centrifugation developed in France by Choukroun et al. A single centrifugation is performed, following which the middle layer obtained, contains the lowest level of red blood cells, and contains almost no platelets, while above there is a layer of plasma. Platelet rich fibrin contains clotting factors that form a fibrin network that traps various cytokines in the PRF. ${ }^{6}$

\section{Clinical Application}

Significantly successful outcomes have been witnessed in the field of osteoregeneration by means of enhancing osteoprogenitor cells in the host bone and in bone grafts, ${ }^{8-10}$ where PRP has shown promising results in combination with autogenous bone graft by Marx and Garg et al, DFBA by Choukran et al and TCP by Saini et al. Bone added osteotome sinus floor elevation supported by Diss et al in conjunction with rapid clinical healing, excellent bone density, less surgical time, less resorption during healing and decreased post-operative pain, as compared to guided bone regeneration procedures ${ }^{8,11-31}$ (Table 1). Acceleration of hard tissue maturation and block graft procedures also produces a quantity of immature hard osteoid tissue within lesser time than the conventional time, hence improves primary stability for implant along with $20 \%$ greater trabecular bone density and $85 \%$ greater proportion of mature haversian system in the initial months supported by no evidence of active resorption and remodeling, indicating a level of stable maturity. 8,32

The main purpose of PRP is to reduce the use of autologous bone graft collected from the patients sites and reducing the mucosal incisions ${ }^{32}$ Though Ozdemir, Raghoebar, Schaaf et al conveyed no beneficial effects of PRP with grafts in their literature ${ }^{33-43}$ (Table 2). 
Table 2: Contradictory evidences of the meta-analysis

\begin{tabular}{|c|c|c|c|}
\hline Sl. no. & Contradictory evidence reported & Authors & Year \\
\hline 1. & $\begin{array}{l}\text { The use of PRP did not improve the result obtained by enamel matrix derivative } \\
\text { and natural bone mineral combined. }\end{array}$ & Döri et al & 2013 \\
\hline 2. & $\begin{array}{l}\text { At } 6 \text { months, no statistical significant reduction of the gingival recession, clinical } \\
\text { attachment level, probing pocket depth and bony defect depth were observed } \\
\text { between group of } \beta-T C P \text { and PRP/ } \beta \text {-TCP combination. }\end{array}$ & $\begin{array}{l}\text { Ozdemir et al and } \\
\text { Döri et al }\end{array}$ & 2012 and 2008 \\
\hline 3. & No significant differences were seen between PRP and collagen membrane in GTR. & Goyal et al & 2011 \\
\hline 4. & $\begin{array}{l}\text { BPBM/GTR/PRP (experimental group) or with BPBM/GTR (control group): no } \\
\text { statistically significant postopertaive difference seen in the probing depth, attachment } \\
\text { levels and bone measurements. }\end{array}$ & Camargo et al & 2009 \\
\hline 5. & $\begin{array}{l}\text { The use of PRP with anorganic bovine bone material (ABBM) failed to improve the } \\
\text { result obtained with ABBM alone. }\end{array}$ & Döri et al & 2009 \\
\hline 6. & $\begin{array}{l}\text { Topical use of PRP did not improve maxillary bone volume compared to convention- } \\
\text { ally treated patients. }\end{array}$ & Schaaf et al & 2008 \\
\hline 7. & $\begin{array}{l}\text { No difference was seen in the treatment of recession with CTG or a CTG-PRP } \\
\text { combination. }\end{array}$ & Keceli et al & 2008 \\
\hline 8. & $\begin{array}{l}\text { Clinical performance across both sites showed no statistical significance. Enhanced } \\
\text { bone activities in sites treated with PRP were seen } 4 \text { months after surgery, but a } \\
\text { progressive extinuishment of the PRP effect is recorded after an interval longer } \\
\text { than } 6 \text { to months. }\end{array}$ & Consolo et al & 2007 \\
\hline 9. & $\begin{array}{l}\text { No significant difference was observed between sites, where PRP or fibrin has been } \\
\text { used as a delivery system for rhBMP-2 (ANOVA). The application of fibrin gels or } \\
\text { PRP gels to bone defects is not superior to leaving the defect untreated. }\end{array}$ & Jung et al & 2005 \\
\hline 10. & $\begin{array}{l}\text { No beneficial effect of PRP when added to autologous bone grafts used for maxillary } \\
\text { sinus. }\end{array}$ & Raghoebar et al & 2005 \\
\hline
\end{tabular}

But, the negative predisposition to the review on PRP could be attributed to the quality of PRP used, techniques to sequester the platelets, use of damaged platelets, not adequately activated platelets, or statistically insufficient data to draw a valid conclusions, distinctive response in animal models, isolation techniques equally holding odds minimal effects of PRP on bone healing. ${ }^{8}$

Wrapping up the literature appears to buttress that PRP may be effective in relatively small periodontal defects when they are grafted with autologous bone. When autologous bone is not present in the graft and there is large volume, PRP may not produce the desired stimulatory response because vital bone cells are needed for this stimulation to occur. ${ }^{44}$

In parallel, PRP placed in extraction sockets have reported early and improved bone formation. 17,22

Tallying up to the various benefits, review has further articled the impact of PRP over soft tissue grafts. Coherent property of PRP helps stabilize the graft over the root surface and on completion of suturing technique. ${ }^{45,46}$

Jankovic and Gassling et al appraised this platelet concentrate to show positive results in gingival and periodontal repair on account of significant reduction in probing pocket depth and mean gain in clinical attachment level with linear bone fill by favoring blood cell adhesion on the root surface. ${ }^{25,27}$ This inference has been supported by Robert Marx who demonstrated with histologic evidence with the aim to explain how PRP enhanced the initial soft tissue migration and re-epithelialization and a higher incidence of wound closure at days 3, 7 and 14 with records taken at 6th day showing no peripheral erythema with $95 \%$ epithelial covering opposed to only $5 \%$ or less epithelialization in controlled split thickness skin graft donor site with no epithelial budding or granulation tissue. Similar supporting data was reported by another study showing more advanced healing at the PRP site at 45 days. ${ }^{8}$ Enhanced bone activities in sites treated with PRP were seen up to 4 months after surgery, but a progressive extinguishment of the PRP effect is recorded after an interval longer than 6 to 7 months. ${ }^{41}$

A combination of direct pulp capping agent and PRP increased vital tissue regeneration within the root canals of immature teeth associated with apical periodontitis. Flaunting its equity as direct pulp capping agent and aiding in the formation of incomplete apex formation, PRP has also step forth in the field of Endodontics. ${ }^{25,27}$

Moving a step further, the introduction of PRF brought in an added boon. Spelling out benefits of precluding use of anticoagulants, a 3D fibrin matrix aiding in cytokine retention for extended periods, formulation of a PRF membrane possessing elasticity and flexibility along with its lucrative simplicity, PRF has demonstrated improved implant bone contact as compared to PRP, though review in literature is yet a small number. Concentration of fibrinogen and growth factors is 12 and eight times more respectively in PRF as compared to PRP. ${ }^{48}$

However, at this stage of investigation, the results are yet far from absolutely conclusive. Much is still unknown 
about PRP, and an adequate body of research should precede a widespread use of this adjunctive material, as would occur with any other biologic agent.

Research has proven various benefits of PRP which rope in decreased incidence of intra and postoperative bleeding and pain amalgamated with diminished potential for rejection bolstering graft acceptance. ${ }^{46}$ But case selection also plays a very important role as its use is refrained in cases where calcification is not a desired outcome, combined with the region of grafting plays a very important role to promote beneficial effects. ${ }^{39}$

Hence undoubtedly, all clinicians involved with bone grafting have high hopes that PRP will eventually prove to be of great benefit in bone graft healing.

\section{CONCLUSION}

Platelet rich plasma has shown a promising outcome in the field of regenerative dentistry. Extensive research has been done in the field of implant, periodontal and oral surgery. But, further evidence is needed in the field of endodontic regenerative science with definition of the specific therapeutic potential.

\section{REFERENCES}

1. Freymiller EG, Aghaloo TL. Platelet-rich plasma: ready or not? J Oral Maxillofac Surg 2004;62(4):484-488.

2. Kim TH, Kim SH, Sádor GK, Kim YD. Comparison of plateletrich plasma, platelet-rich fibrin, and concentrated growth factor in rabbit-skull defect healing. Arch Oral Biol 2014 May;59(5):550-558.

3. Whitmann DH, Berry RL, Green DM. Platelet gel: an alternative to fibrin glue with applications in oral and maxillofacial surgery. J Oral Maxillofac Surg 1997;55(11):1294-1299.

4. Sánchez AR, Sheridan PJ, Kupp LI. Is platelet-rich plasma the perfect enhancement factor? A current review. Int J Oral Maxillofac Implant 2003;18:93.

5. Dohan DM, Choukroun J, Diss A, Dohan SL, Dohan AJ, Mouhyi J, et al. Platelet-rich fibrin: a second-generation platelet concentrate-part I: technological concepts and evolution. Oral Surg Oral Med Oral Pathol Oral Radiol Endod 2006;101(3):e37-44.

6. Kiran NK, Mukunda KS, Tilak TN. Platelet concentrates: a promising innovation in dentistry. J Dent Sci Res 2011;2(1): 50-61.

7. Marx R. Platelet rich plasma: what is PRP and what is not PRP? Implant Dentistry 2001;10(4):225-228.

8. Marx RE. Platelet-rich plasma: evidence to support its use. J Oral Maxillofac Surg 2004;62(4):489-496.

9. Marx RE, Carlson ER, Eichstaedt R, et al. Platelet rich plasma: growth factor enhancement for bone grafts. Oral Surg Oral Med Oral Pathol Oral Radiol Endod 1998;85(6):638-646.

10. Weibrich G, Gnoth SH, Otto M, et al. Growth stimulation of human osteoblast-like cells by thrombocyte concentrates in vitro. Mund Kiefer Geschtschir 2002;6(3):168-174.

11. Bajaj P, Pradeep AR, Agarwal E, Rao NS, Naik SB, Priyanka N, Kalra N. Comparative evaluation of autologous platelet-rich fibrin and platelet-rich plasma in the treatment of mandibular degree II furcation defects: a randomized controlled clinical trial. J Periodontal Res 2013 Oct;48(5): 573-581.

12. Pradeep AR, Rao NS, Agarwal E, Bajaj P, Kumari M, Naik SB. Comparative evaluation of autologous platelet-rich fibrin and platelet-rich plasma in the treatment of 3-wall intrabony defects in chronic periodontitis: a randomized controlled clinical trial. J Periodontol 2012 Dec;83(12):1499-1507.

13. Zhu W, Zhu X, Huang GT, Cheung GS, Dissanayaka WL, Zhang C. Regeneration of dental pulp tissue in immature teeth with apical periodontitis using platelet-rich plasma and dental pulp cells. Int Endod J 2013 Oct;46(10):962-970.

14. Jadhav G, Shah N, Logani A. Revascularization with and without platelet-rich plasma in nonvital, immature, anterior teeth: a pilot clinical study. J Endod 2012 Dec;38(12):1581-1587.

15. Menezes LM, Rao J. Long-term clinical evaluation of plateletrich plasma in the treatment of human periodontal intraosseous defects: a comparative clinical trial. Quintessence Int 2012 Jul-Aug;43(7):571-582.

16. Kutkut A, Andreana S, Kim HL, Monaco E Jr. Extraction socket preservation graft before implant placement with calcium sulfate hemihydrate and platelet-rich plasma: a clinical and histomorphometric study in humans. J Periodontol 2012 Apr;83(4):401-409.

17. Rutkowski JL, Johnson DA, Radio NM, Fennell JW. Platelet rich plasma to facilitate wound healing following tooth extraction. J Oral Implantol 2010;36(1):11-23.

18. Antonello Gde M, Torres do Couto R, Giongo CC, Corrêa $\mathrm{MB}$, Chagas Júnior OL, Lemes CH. Evaluation of the effects of the use of platelet-rich plasma on alveolar bone repair following extraction of impacted third molars: prospective study. J Craniomaxillofac Surg 2013 Jun;41(4):e70-75.

19. Parikh B, Navin S, Vaishali P. A comparative evaluation of healing with a computed tomography scan of bilateral periapical lesions treated with and without the use of plateletrich plasma. Ind J Dent Res 2011 May-Jun;22(3):497-498.

20. Saini N, Sikri P, Gupta H. Evaluation of the relative efficacy of autologous platelet-rich plasma in combination with $\beta$-tricalcium phosphate alloplast versus an alloplast alone in the treatment of human periodontal infrabony defects: a clinical and radiological study. Ind J Dent Res 2011 JanFeb;22(1):107-115.

21. Kaushick BT, Jayakumar ND, Padmalatha O, Varghese S. Treatment of human periodontal infrabony defects with hydroxyapatite $+\beta$-tricalcium phosphate bone graft alone and in combination with platelet rich plasma: a randomized clinical trial. Ind J Dent Res 2011 Jul-Aug;22(4):505-510.

22. Sammartino G, Tia M, Marenzi G, Lauro AE, D'Agostino E, Claudio PP. Use of autologous platelet-rich plasma in periodontal defect treatment after extraction of impacted mandibular third molars. Oral Surg Oral Med Oral Pathol Oral Radiol Endod 2008 May;105(5):572-579.

23. Ogundipe OK, Ugboko VI, Owotade FJ. Can autologous platelet-rich plasma gel enhance healing after surgical extraction of mandibular third molars? J Oral Maxillofac Surg 2011 Sep;69(9):2305-2310.

24. Camargo PM, Lekovic V, Weinlaender M, Vasilic N, Madzarevic M, Kenney EB. Platelet-rich plasma and bovine porous bone mineral combined with guided tissue regeneration in the treatment of intrabony defects in humans. J Periodontal Res 2002 Aug;37(4):300-306. 
25. Gassling VL, Açil Y, Springer IN, Hubert N, Wiltfang J. Platelet-rich plasma and platelet-rich fibrin in human cell culture. Oral Surg Oral Med Oral Pathol Oral Radiol Endod 2009 Jul;108(1):48-55.

26. Diss A, Dohan DM, Mouhyi J, Mahler P. Osteotome sinus floor elevation using Choukroun's platelet-rich fibrin as grafting material: a 1-year prospective pilot study with microthreaded implants. Oral Surg Oral Med Oral Pathol, Oral Radiol Endod 2008;105(5):572-579.

27. Jankovic SM, Zoran AM, Vojislav LM, et al. The use of platelet rich plasma in combination with connective tissue grafts following treatment of gingival recessions. J Perio 2007;4(1) 63-71.

28. Choukroun J, Diss A, Simonpieri A, Girard MO, Schoeffler C, Dohan SL, Dohan AJ, Mouhyi J, Dohan DM. Platelet rich fibrin: a second generation platelet concentrate. Part V: histologic evaluations of PRF effects on bone allograft maturation in sinus lift. Oral Surg Oral Med Oral Pathol Oral Radiol Endod 2006;101:299-303.

29. Keswani D, Pandey RK, Ansari A, Gupta S. Comparative evaluation of platelet-rich fibrin and mineral trioxide aggregate as pulpotomy agents in permanent teeth with incomplete root development: a randomized controlled trial. J Oral Maxillofac Surg 2005 Jun;63(6):766-770.

30. Garg AK. The use of platelet rich plasma to enhance the success of bone grafts around dental implants. Dent Implantol Update 2000;11(3):17-21.

31. Danesh-Meyer $\mathrm{MJ}^{1}$, Filstein MR. Histological evaluation of sinus augmentation using platelet rich plasma: a case series. Shanaman RJ Int Acad Periodontol 2001 Apr;3(2):48-56.

32. Forni F, Marzagalli M, Tesei P, Grassi A. Platelet gel: applications in dental regenerative surgery. Blood Transfus 2013 Jan;11(1):102-107.

33. Döri F, Arweiler N, Húszár T, Gera I, Miron RJ, Sculean A. Five-year results evaluating the effects of platelet-rich plasma on the healing of intrabony defects treated with enamel matrix derivative and natural bone mineral. J Periodontol 2013 Nov;84(11):1546-1555.

34. Ozdemir B, Okte E. Treatment of intrabony defects with beta-tricalciumphosphate alone and in combination with platelet-rich plasma. J Biomed Mater Res B Appl Biomater 2012 May;100(4):976-983.

35. Döri F, Huszár T, Nikolidakis D, Tihanyi D, Horváth A, Arweiler NB, Gera I, Sculean A. Effect of platelet-rich plasma on the healing of intrabony defects treated with Beta tricalcium phosphate and expanded polytetrafluoroethylene membranes. J Periodontol 2008 Apr;79(4):660-669.

36. Goyal B, Tewari S, Duhan J, Sehgal PK. Comparative evaluation of platelet-rich plasma and guided tissue regeneration membrane in the healing of apicomarginal defects: a clinical study. J Endod 2011 Jun;37(6):773-780.
37. Camargo PM, Lekovic V, Weinlaender M, Divnic-Resnik T, Pavlovic M, Kenney EB. A surgical re-entry study on the influence of platelet-rich plasma in enhancing the regenerative effects of bovine porous bone mineral and guided tissue regeneration in the treatment of intrabony defects in humans. J Periodontol 2009 Jun;80(6):915-923.

38. Döri F, Kovács V, Arweiler NB, Huszár T, Gera I, Nikolidakis D, Sculean A. Effect of platelet-rich plasma on the healing of intrabony defects treated with an anorganic bovine bone mineral: a pilot study. J Periodontol 2009 Oct;80(10):1599-1605.

39. Schaaf $\mathrm{H}$, Streckbein $\mathrm{P}$, Lendeckel S, Heidinger KS, Rehmann P, Boedeker RH, Howaldt HP. Sinus lift augmentation using autogenous bone grafts and platelet-rich plasma: radiographic results. Oral Surg Oral Med Oral Pathol Oral Radiol Endod 2008 Nov;106(5):673-678.

40. Keceli HG, Sengun D, Berberoğlu A, Karabulut E. Use of platelet gel with connective tissue grafts for root coverage: a randomized-controlled trial. J Clin Periodontol 2008 Mar;35(3):255-262.

41. Consolo U, Zaffe D, Bertoldi C, Ceccherelli G. Platelet-rich plasma activity on maxillary sinus floor augmentation by autologous bone. Clin Oral Implants Res 2007 Apr;18(2): 252-262.

42. Jung RE, Schmoekel HG, Zwahlen R, Kokovic V, Hammerle $\mathrm{CH}$, Weber FE. Platelet-rich plasma and fibrin as delivery systems for recombinant human bone morphogenetic protein-2. Clin Oral Implants Res 2005 Dec;16(6):676-682.

43. Raghoebar GM, Schortinghuis J, Liem RS, Ruben JL, van der Wal JE, Vissink A. Does platelet-rich plasma promote remodeling of autologous bone grafts used for augmentation of the maxillary sinus floor? Clin Oral Implants Res 2005 Jun;16(3):349-356.

44. Froum SJ, Wallace SS, Tarnow DP, Sang-Choon Cho, Effect of platelet-rich plasma on bone growth and osseointegration in human maxillary sinus grafts: three bilateral case reports. Int J Period Rest Dent 2002;22(1):45-53.

45. Aroca S, Keglevich T, Barbieri B, Gera I, Etienne D. Clinical evaluation of a modified coronally advanced flap alone or in combination with a platelet-rich fibrin membrane for the treatment of adjacent multiple gingival recessions: a 6-month study. J Periodontol 2009;80(2):244-252.

46. Petrungaro PS. Using platelet-rich plasma to accelerate soft tissue maturation in esthetic periodontal surgery. Compend Contin Educ Dent 2001 Sep;22(9):729-732.

47. Zhu X1, Zhang C, Huang GT, Cheung GS, Dissanayaka WL, Zhu W. Transplantation of dental pulp stem cells and platelet-rich plasma for pulp regeneration. J Endod 2012 Dec; 38(12):1604-1609.

48. You TM, Choi BH, Zhu SJ, Jung JH, LeeSH, Huh JY, Lee HJ, Li J. Platelet-enriched fibrin glue and platelet-rich plasma in the repair of bone defects adjacent to titanium dental implants. Int J Oral Maxillofac Implants 2007 May-Jun;22(3):417-422. 